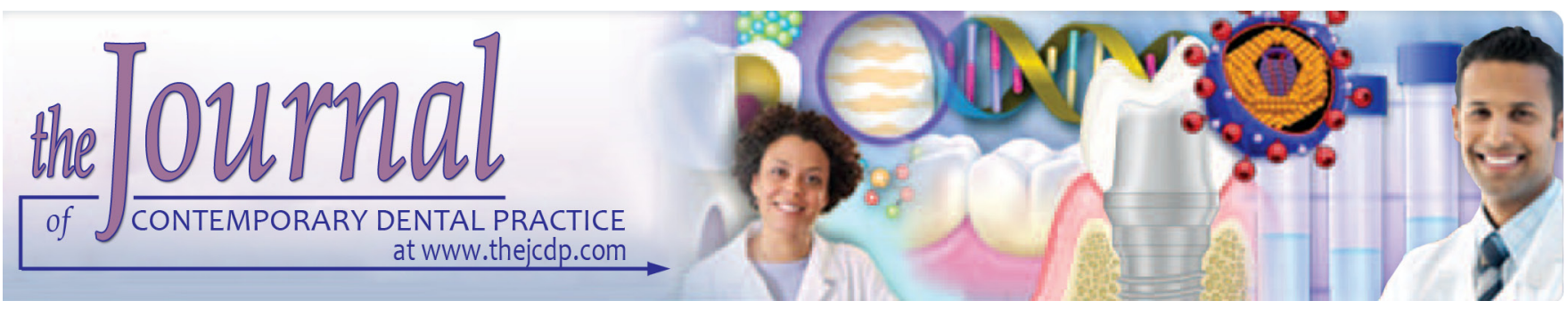

\title{
Advances in Soft Denture Liners: An Update
}

\author{
Mohammed Ibrahim Hashem
}

\begin{abstract}
Soft denture liners are used in complete and partial removable dentures to distribute functional loads homogeneously on the denture-bearing tissues. These materials are recommended in cases of irregular bone resorption, bony undercuts, thin atrophic mucosa, immediate prosthesis, healing after implant placement, and for patients with bruxism and xerostomia. The resilient lining materials can be categorized as plasticized acrylic resins or silicone elastomers. The plasticized acrylic resin comprises of acrylic polymers and copolymers, a liquid containing an acrylic monomer and plasticisers, such as ethyl alcohol and/or ethyl acetate responsible for preserving the material softness. The silicone elastomers, consisting of dimethylsiloxane polymers, with a chemical composition similar to that of the silicone impression materials devoid of leachable plasticisers, retain their elastic properties for prolonged periods. Most of the currently available materials have several disadvantages, including color stability, long-term resiliency, abrasion resistance, bond strength and porosity. Several modifications have been done recently to overcome of these disadvantages of the soft liners. The current review summarizes the recent developments in soft liners.
\end{abstract}

Keywords: Soft denture liner, Dental materials, Hardness, Color, Absorption, Solubility, Silicone.

How to cite this article: Hashem MI. Advances in Soft Denture Liners: An Update. J Contemp Dent Pract 2015;16(4):314-318.

Source of support: Nil

Conflict of interest: None

\section{INTRODUCTION}

Soft denture reliners are materials forming a cushioned layer between the hard denture base and the oral mucosa.

Department of Dental Health, College of Applied Medical Sciences, King Saud University, Riyadh, Saudi Arabia; Department of Dental Biomaterials, Al-Azhar University, Cairo Egypt

Corresponding Author: Mohammed Ibrahim Hashem Assistant Professor, Department of Dental Health, College of Applied Medical Sciences, King Saud University, Riyadh, Saudi Arabia, e-mail: codriyadh@gmail.com
The liners help in distributing more evenly the forces of mastication to the underlying tissues by absorbing some of the masticatory forces. ${ }^{1}$ The soft liners have the potential of improving comfort to denture patients with ridge atrophy, thin and non resilient mucosa, bony undercuts and bruxomania. ${ }^{2}$ They are also recommended in cases of irregular bone resorption, immediate prosthesis, healing after implant placement, and for patients with bruxism and xerostomia. ${ }^{3,4}$ The success or failure of a soft liner is dependent not only upon the physical properties of the material employed, but also on the understanding of the intended function of these products, and the physiological and biological properties of resilient oral tissues upon which the denture rests.

Soft denture reliners can be divided into semipermanent or permanent. It is further subdivided into silicone rubbers or plasticized acrylics and can be either auto-heat or visible light polymerized. ${ }^{5}$ Resilient lining materials can be categorized as plasticized acrylic resins or silicone elastomers. The plasticized acrylic resin comprises of a powder consisting of acrylic polymers and copolymers and a liquid containing an acrylic monomer. The plasticisers are responsible for maintaining the material softness. ${ }^{6}$ The silicone elastomers, consisting of dimethylsiloxane polymers, with a chemical composition similar to that of the silicone impression materials, are not dependent on leachable plasticisers and, therefore, retain their elastic properties for prolonged periods. ${ }^{7}$ The physical properties desirable in a soft liner material are a cushioning effect on the mucosa, dimensional stability, permanent resilience, minimal fluid sorption and solubility, and inhibitory action on fungal growth. The desirable mechanical properties are ease of processing, ease of finishing and polishing, and adhesion to, but no effect upon, denture resin. ${ }^{8}$

One major indication for soft liners is to reduce problems arising from the effects of age changes in the denture bearing tissues. The use of a soft liner can improve both masticatory efficiency and oral comfort 
for patients presenting a reduced thickness of the oral mucoperiosteum. ${ }^{9}$

\section{Short-term vs Long-term Soft Liners}

Short-term liners or tissue conditioners are used immediately after surgery. These tissue conditioners usually consist of poly ethyl methacrylate powder, aromatic esters and alcohol. These materials are devoid of methacrylate monomers. ${ }^{10}$ The tissue conditioners may be used for a few days to a week but they should always be used as short-term materials. Long-term soft liners are usually either a plasticized acrylic or a silicone. Plasticized acrylics usually have a shorter service life because of hardening and water sorption. ${ }^{11}$ They have a similar composition to that of denture base polymers with a high percentage of plasticizers. Plasticizers keep these materials soft, but this property is lost overtime. Acrylic soft liners could be used for up to 6 months.

Long-term silicone soft liners are usually used for up to 1 year. Currently, room temperature polymerizing vinyl polysiloxane materials, which have a similar chemistry to silicone impression materials are used. Silicone soft liners face problems in establishing a durable bond with the denture base. This can be solved by the use of suitable solvent based primers or other mechanical methods.

\section{Soft Lining Materials and Tissue Conditioners}

Tissue conditioners are soft denture liners which may be applied to the fitting surface of a denture. Soft liners are used to absorb some of the energy produced by masticatory impact and act as a 'shock absorber'. Some patients suffer from chronic pain, soreness or discomfort due to prolonged contact between the rigid denture base materials and the underlying tissues; usually in patients with sharp, thin, or heavily resorbed ridges or those with severe undercuts. The soft lining materials include: plasticized acrylics, silicone rubber, plasticized vinyl polymers and copolymers, hydrophilic polymers, polyphosphazine fluoropolymers, fluoroethylene and polyvinyl siloxane addition silicones. The most commonly used soft liners are plasticized acrylics and silicone rubber which are heat- or chemically-activated. ${ }^{12}$

The tissue conditioners or short-term soft liners are commonly used as temporary liners for treatment and conditioning of ill-fitting dentures, for provisional or diagnostic purposes, temporary relining of immediate dentures or immediate surgical splints, relining cleft palate speech aids, tissue conditioning during implant healing and for functional impression materials. The liquid of short-term soft liner materials contains a mixture of ethyl alcohol (solvent) and an aromatic ester (dibutyl phthalate) which acts as a plasticizer that lowers the glass transition temperature (Tg) of the polymer rendering it a soft gel. The set gel has viscoelastic and elastic properties that allow it to act as a shock absorber. However, the alcohol and plasticizer leach out quickly, and therefore, the material hardens within a considerably short time, which varies from a few days to a week or two, and gradually loses its cushioning effect. Ideally, a tissue conditioner should be replaced with a fresh mix every 2 to 3 days. Another application of tissue conditioners is as functional impression materials. A layer of tissue conditioner in the fitting surface of the denture enables a functional impression to be obtained over a period of a few days. ${ }^{13}$

Temporary soft liners are often used in place of tissue conditioners in cases where it is not practicable to replace the conditioner every 2 to 3 days. In addition, they may be used as a means of temporarily improving the fit of an ill-fitting denture until such a time as a new denture can be constructed. Another use of the products is as a diagnostic aid to ascertain whether the patient would benefit from a permanent soft lining. Both tissue conditioners and temporary soft lining materials will go hard. When this occurs the surface becomes both rough and irregular, increasing the risk of trauma. In addition, these materials can be relatively easily colonized by Candida in this hardened state, increasing the risk of a denture-induced stomatitis. It is possible to soak such dentures overnight in dilute sodium hypochlorite to help to mitigate infection risk. ${ }^{14}$

A number of problems associated with the use of reliners have been reported, such as porosity, loss of softness, debonding from the denture base, rough surface, color changes, colonization by microorganisms and poor tear strength. Currently, several measures are undertaken to overcome some of these issues.

\section{METHODS TO IMPROVE THE ADHESION OF DENTURE LINERS}

\section{Bond Strength of Liners}

The major drawbacks of the soft liners are the lack of a durable bond to denture base. Detachment of soft liners from the denture base is a common clinical occurrence. The bond strength of resilient liners depends upon the tensile strength of the materials. A reliable bond between denture base and soft liner is required for the denture to function properly. ${ }^{15}$ Failure of adhesion between denture base and liners creates an environment which renders bacterial colonization and also compromise the durability of the soft liner. Factors that affect the bond between acrylic and liner are the geometry of surface, etching, use of bonding agents, and the thickness of lining materials. 
Several techniques are employed to improve bond strength and adhesion of the liners. Creation of roughness of acrylic interface with the aid of lasers, alumina abrasion has been tried to resolve the problem. ${ }^{16}$ Chemical etching of the surface with MMA, acetone, or methylene chloride are used to increase the bond strength as well as reinforcement of the acrylic surfaces with net woven fibers of glass. ${ }^{17,18}$ Alternative surface roughening method, namely oxygen plasma treatment, has also show to improve the tensile bond strength between denture base resin and soft liner. ${ }^{19}$

\section{MODIFICATIONS TO PREVENT MICROBIAL OVERGROWTH}

\section{Addition of Silver Nanoparticles}

One of the problems encountered while using soft denture liners is the growth of microorganisms. ${ }^{20,21}$ Microorganisms initially adhere to the surface of the lining and then they penetrate inside the material. Studies have shown that the use of soft lining materials can intensify the process of the fungal and bacterial growth which is supported by environmental conditions under the denture as well as the structure of materials. ${ }^{22}$ This phenomenon is particularly disadvantageous, because it shows restricted possibilities of conventional cleaners commonly used by patients.

Silver (Ag) has been well known for its antimicrobial characteristic and has a long history of application in medicine with a well-tolerated tissue response and low toxicity profile and is more toxic than many other metals against a broad spectrum of sessile bacteria and fungi which colonize on plastic surface. ${ }^{23}$ Modification of soft linings by AgNPs can be used because of their fungicidal and bactericidal properties of silver. ${ }^{24}$ Studies revealed that the antifungal and antibacterial properties of the denture base can be substantially improved by the addition of silver nanoparticles. ${ }^{25,26}$

\section{Incorporation of Antifungal Agents}

One possible strategy is to incorporate an antifungal agent into a tissue conditioner. An antifungal agent incorporated into a tissue conditioner can provide a slow continuous release resulting in a sustained therapeutic effect. The drugs, such as chlorhexidine, clotrimazole, fluconazole and nystatin were tried and have shown to inhibit the growth of C. albicans, indicating the release of the drugs from the liner. ${ }^{27}$ Incorporation of miconazole as powder or gel form has potent inhibitory against C. albicans. ${ }^{27,28}$

\section{Surface Alteration by Sealer Coating}

The clinical performance of the soft liners surface sealers can be used to protect the material against the external environment stress caused by mechanical and chemical factors. The sealed soft liners remain clean and resilient for a longer period than non-sealed materials, and also reduce microorganism growth and biofilm formation. ${ }^{29,30}$ The sealer acts as a mechanical barrier to decrease water sorption and solubility of chemical components. It can also control the accumulation of food debris and biofilm formation is reduced with a smooth sealed surface, as well as the risk for mucosa inflammation decreases due to a less contaminated and irritating surface. ${ }^{31,32}$ The properties of sealed soft liners may be affected by routine cleaning methods, such as soaking in chemical agents and mechanical brushing. ${ }^{33,34}$ However, studies have shown that the sealer coating substantially reduced the surface degradation of the soft liners. ${ }^{35,36}$

\section{Color Stability of Liners}

Discoloration of denture base materials is observed after long-term use by accumulation of stain, absorption of water, dissolution of ingredients and intrinsic pigments degradation. Beverages, such as tea which contain flavonoids and methyl xanthine, coffee which contain nicotine, caffeine and caffeic acid wine, artificial dyes as part of food, smoking and microbial colonization and pigments in the liner also contribute for discoloration. ${ }^{37}$ Fluorinated soft lining materials have shown better color stability and improved resistance to stains. The leaching of plasticizers creates space incorporating staining pigments which is accentuated by rough surfaces. ${ }^{38}$

\section{Water Sorption}

Water sorption by lining material leads to change in dimension and stress concentration at liner-denture base interface leading to reduction of bond strength. The type of filler used and its bonding to the polymer is responsible for water absorption. The heat polymerized silicone has better bond to filler and greater cross-linking leading to the production of a denser material which are devoid of micro pockets of water within the material. ${ }^{39}$

\section{DISCUSSION}

Soft denture liner materials have been used in dentistry for more than a century, with the earliest soft liners being natural rubbers. The international standard organization (ISO) in 1999 defined soft denture lining material as a soft resilient material bonded to the fitting surface of a denture to reduce trauma to the supporting tissues. 
These materials have been used as a cushion on the intaglio surfaces of the dentures in patients who suffer from traumatized oral mucosa, ridge atrophy, bony undercuts, bruxism, xerostomia, congenital oral defects requiring obturation, and for improving the retention of the dentures by engaging undercuts. ${ }^{10}$ Soft liners are mostly used for reducing local point pressures. They usually act as a cushion to distribute the masticatory forces transmitted to the underlying tissues but they do not necessarily decrease the force transmitted. They are mainly used for patients with a sharp alveolar ridge, thin atrophic mucosa, normal mucosa with a resorbed ridge and when mucosa shows a low tolerance to the load applied by denture.

Desirable properties for lining materials should include: (1) high bond strength to the denture base, (2) dimensional stability, (3) permanent softness or resilience, (4) low water sorption, (5) color stability, (6) ease of processing and (7) biocompatibility. Several materials have been used as liners, such as plasticized acrylic, vinyl polymers and copolymers, fluoroelastomer, silicon rubber and natural rubber. Although, the properties of soft lining materials have been much improved, they still have several drawbacks. Soft denture liners have several problems associated with their use such a loss of softness, water sorption, colonization of Candida Albicans and adhesion failure between liner and denture base. Therefore, frequent clinical evaluation and periodic replacement of soft denture liner are needed.

Pretreatment of the denture base surface is carried out to augment the bond strength between the denture base and the denture liner. The use of organic solvents increases the bond strength between denture liners and denture bases. Chemical etchants, such as monomethyl methacrylate, acetone, or methylene chloride have been used to increase the bond strength of repair material to polymethyl methacrylate denture base. High water sorption and solubility, and a gradual hardening due to plasticizer leaching out, are the main drawbacks of plasticized acrylics. Although silicone materials have a longer duration of resilience, their adhesion to acrylic denture base materials is not optimal. The hydrophobicity of the silicone materials reduces water sorption, but simultaneously inhibits good affinity to the supporting tissues.

A polyisoprene-based light-curing lining material, with interpenetrating polymer networks of polyisopreneelastomer and higher alkyl methacrylate, has recently been developed for resolving some of the issues related to the currently available liners. Since the polyisopreneelastomers, being different from the plasticizer in plasticized acrylic, will not leach out and has light-curing property, allows clinicians to ensure that the relining procedure is accurate before curing. It appears that this new material would be a potential soft material for relining the denture.

\section{CONCLUSION}

Denture soft liner has a considerable role in removable prosthodontics because of its cushioning effect and its ability to redistribute masticatory forces transmitted to the denture bearing area. The soft lining materials used for short- and long-term can be categorized into plasticized acrylic and silicone types.

The choice for a soft liner for clinical use should be based on the materials biocompatibility, mechanical properties and durability in the oral environment. However, these lining materials may present physical and mechanical problems during clinical application, such as color alteration, loss of plasticizer and resilience, poor rupture strength and porosity. Currently, newer generation of materials and methods is tried to overcome these inherent properties of the soft liners.

\section{REFERENCES}

1. McCabe JF, Carrick TE, Kamohara H. Adhesive bond strength and compliance for denture soft lining materials. Biomaterials 2002;23(5):1347-1352.

2. Murata H, Taguchi N, Hamada T, Kawamura M, McCabe JF. Dynamic viscoelasticity of soft liners and masticatory function. J Dent Res 2002;81(2):123-128.

3. Dootz ER, Koran A, Craig RG. Physical property comparison of 11 soft denture lining materials as a function of accelerated aging. J Prosthet Dent 1993;69(1):114-119.

4. Gjengedal H, Berg E, Gronningsaeter AG, Dahl L, Malde MK, Boe OE, et al. The influence of relining or implant retaining existing mandibular dentures on health-related quality of life: a 2-year randomized study of dissatisfied edentulous patients. Int J Prosthodont 2013;26(1):68-78.

5. Ergun G, Nagas IC. Color stability of silicone or acrylic denture liners: an in vitro investigation. Eur J Dent 2007; 1(3):144-151.

6. Gronet PM, Driscoll CF, Hondrum SO. Resiliency of surfacesealed temporary soft denture liners. J Prosthet Dent 1997;77(4):370-374.

7. McCabe JF. Soft lining materials: composition and structure. J Oral Rehabil 1976;3(3):273-278.

8. Pesun IJ, Villar A, Hodges JS, DeLong R, Lai JH, Schneider D. Development of a nondestructive compliance test for resilient denture liners. J Prosthodont 2001;10(2):91-96.

9. Kydd WL, Daly CH, Nansen D. Variation in the response to mechanical stress of human soft tissues as related to age. J Prosthet Dent 1974;32(5):493-500.

10. Garcia LT, Jones JD. Soft liners. Dent Clin North Am 2004;48(3):709-720.

11. Parker S, Braden M. Water absorption of methacrylate soft lining materials. Biomaterials 1989;10(2):91-95.

12. Zarb GA, Bolender CL, Eckert S, Jacob R, Fenton A, MericskeStern R. Prosthodontic treatment for edentulous patients. Complete dentures and implant-supported prostheses. 12th. ed. St. Louis: Mosby 2004. 
13. McCarthy JA, Moser JB. Tissue conditioners as functional impression materials. J Oral Rehabil 1978;5(4):357-364.

14. Harrison A, Basker RM, Smith IS. The compatibility of temporary soft materials with immersion denture cleansers. Int J Prosthodont 1989;2(3):254-258.

15. Kawano F, Dootz ER, Koran A, 3rd, Craig RG. Comparison of bond strength of six soft denture liners to denture base resin. J Prosthet Dent 1992;68(2):368-371.

16. Usumez A, Inan O, Aykent F. Bond strength of a silicone lining material to alumina-abraded and lased denture resin. J Biomed Mater Res B Appl Biomater 2004;71(1):196-200.

17. Mutluay MM, Ruyter IE. Evaluation of bond strength of soft relining materials to denture base polymers. Dent Mater 2007;23(11):1373-1381.

18. Hatamleh MM, Maryan CJ, Silikas N, Watts DC. Effect of net fiber reinforcement surface treatment on soft denture liner retention and longevity. J Prosthodont 2010;19(4):258-262.

19. Zhang H, Fang J, Hu Z, Ma J, Han Y, Bian J. Effect of oxygen plasma treatment on the bonding of a soft liner to an acrylic resin denture material. Dent Mater J 2010;29(4):398-402.

20. Bulad K, Taylor RL, Verran J, McCord JF. Colonization and penetration of denture soft lining materials by Candida albicans. Dent Mater 2004;20(2):167-175.

21. Graham BS, Jones DW, Burke J, Thompson JP. In vivo fungal presence and growth on two resilient denture liners. J Prosthet Dent 1991;65(4):528-532.

22. Masella RP, Dolan CT, Laney WR. The prevention of the growth of Candida on silastic 390 soft liner for dentures. J Prosthet Dent 1975;33(3):250-257.

23. Nam KY. In vitro antimicrobial effect of the tissue conditioner containing silver nanoparticles. J Adv Prosthodont 2011; 3(1):20-24.

24. Tanagawa M, Yoshida K, Matsumoto S, Yamada T, Atsuta M. Inhibitory effect of antibacterial resin composite against Streptococcus mutans. Caries Res 1999;33(5):366-371.

25. Fan C, Chu L, Rawls HR, Norling BK, Cardenas HL, Whang K. Development of an antimicrobial resin: a pilot study. Dent Mater 2011;27(4):322-328.

26. Chladek G, Barszczewska-Rybarek I, Lukaszczyk J. Developing the procedure of modifying the denture soft liner by silver nanoparticles. Acta Bioeng Biomech 2012;14(1):23-29.

27. Radnai M, Whiley R, Friel T, Wright PS. Effect of antifungal gels incorporated into a tissue conditioning material on the growth of Candida albicans. Gerodontology 2010;27(4): 292-296.

28. Quinn DM. The effectiveness, in vitro, of miconazole and ketoconazole combined with tissue conditioners in inhibiting the growth of Candida albicans. J Oral Rehabil 1985;12(2): 177-182.

29. Tanimoto Y, Saeki H, Kimoto S, Nishiwaki T, Nishiyama N. Evaluation of adhesive properties of three resilient denture liners by the modified peel test method. Acta Biomater 2009;5(2):764-769.

30. Malmstrom HS, Mehta N, Sanchez R, Moss ME. The effect of two different coatings on the surface integrity and softness of a tissue conditioner. J Prosth Dent 2002;87(2):153-157.

31. Boscato N, Delavi JD, Muller L, Pereira-Cenci T, Imanishi $\mathrm{SW}$. Influence of varnish application on a tissue conditioner: analysis of biofilm adhesion. Gerodontol 2010;27(3): 207-210.

32. Ozdemir KG, Yilmaz H, Yilmaz S. In vitro evaluation of cytotoxicity of soft lining materials on L929 cells by MTT assay. J Biomed Mater Res B Appl Biomater 2009;90(1):82-86.

33. Oliveira LV, Mesquita MF, Henriques GE, Consani RL. The effect of brushing on surface roughness of denture lining materials. J Prosthod 2007;16(3):179-184.

34. Oliveira LV, Mesquita MF, Henriques GE, Consani RL, Fragoso WS. Effect of polishing technique and brushing on surface roughness of acrylic resins. J Prosthodont 2008;17(4):308-311.

35. Mainieri VC, Beck J, Oshima HM, Hirakata LM, Shinkai RS. Surface changes in denture soft liners with and without sealer coating following abrasion with mechanical brushing. Gerodontol 2011;28(2):146-151.

36. Mante FK, Mante MO, Petropolous VC. In vitro changes in hardness of sealed resilient lining materials on immersion in various fluids. J Prosthod 2008;17(5):384-391.

37. Imirzalioglu P, Karacaer O, Yilmaz B, Ozmen Msc I. Color stability of denture acrylic resins and a soft lining material against tea, coffee and nicotine. J Prosth 2010;19(2):118-124.

38. Canay S, Hersek N, Tulunoglu I, Uzun G. Evaluation of colour and hardness changes of soft lining materials in food colorant solutions. J Oral Rehabil 1999;26(10):821-829.

39. Waters MG, Jagger RG, Winter RW. Water absorption of (RTV) silicone denture soft lining material. J Dent 1996;24(1-2): 105-108. 